A.I. Engloner, D. Szegö 2016. Genetic diversity of riverine reed stands indicating the water regime of the habitat. Ecological Indicators 61: 846-849. dx.doi.org/10.1016/j.ecolind.2015.10.037

\title{
Genetic diversity of riverine reed stands indicating the water regime of the habitat
}

\author{
Attila I. Engloner*, Dóra Szegő
}

Danube Research Institute of Centre for Ecological Research, Hungarian Academy of

Sciences, Karolina 29, Budapest H-1113, Hungary

*Corresponding author. Tel.: +36 12793107 , E-mail address:

engloner.attila@okologia.mta.hu

\section{Abstract}

Although genetic diversity of reed stands developing in habitats with unchanged water levels have been frequently investigated, little is known about reed propagation along rivers, where fluctuating water levels may provide various conditions for germination and seedling development.

The present paper evaluates genetic diversity of reed stands grown in (i) an oxbow with significant water level fluctuations related to the flood events in the main river; (ii) a separated oxbow which has lost connection to the main channel; and (iii) artificially controlled running water with low water level fluctuation. At each site, reed stands were investigated along transects parallel to the shore and multilocus phenotypes were determined by microsatellite analysis. 
A.I. Engloner, D. Szegő 2016. Genetic diversity of riverine reed stands indicating the water regime of the habitat. Ecological Indicators 61: 846-849. dx.doi.org/10.1016/j.ecolind.2015.10.037

The results demonstrated that genetic diversity of riverine reed stands can indicate the water regime of the habitat. Reed colonizes mostly by vegetative propagation where regular inundation can impede germination and seedling development and, therefore, genetic diversity is low in the whole stand. If a former oxbow becomes practically a lake, the clonal diversity and colonization processes are similar to those observed in regular lakes; clone number decreases towards the open water. When reed forms floating mats (i.e. the effect of water level fluctuation is excluded), generative reproduction prevails in the entire stand, resulting in high genetic diversity even at the open water edge of the stand.

Keywords: microsatellite analysis, riparian habitats, reed colonization

\section{Introduction}

Lakeshores and riverbanks are frequently populated by extensive stands of reed (Phragmites australis (Cav.) Trin. ex Steud.) which play important and complex roles in aquatic ecosystems. Among others, reed stands provide food and habitat for other organisms and take part in the purification of water and protection of the shore (see the review by Kiviat 2013 and the literature cited therein). These roles depend, however, on the stability of stands and their ability to adapt to site conditions. The latter is related to genetic diversity since, as Neuhaus et al. (1993) emphasized, 'the higher the number of clones in a stand, the better is their ability to adapt to unfavorable conditions'. According 
A.I. Engloner, D. Szegö 2016. Genetic diversity of riverine reed stands indicating the water regime of the habitat. Ecological Indicators 61: 846-849. dx.doi.org/10.1016/j.ecolind.2015.10.037

to the hypothesis of Koppitz et al. (1997) and Koppitz and Kühl (2000), reed is

established in three main stages, namely (i) generative propagation ('Settlement'); (ii) expansion of new, suitable clones and selection of the best adapted ones ('Propagation and Establishment') and (iii) competition between reed clones leading to the selection of a few but well adapted clones with narrow ecological tolerance ('Stationary stage'). Effects of water depth on the above stages and reed establishment in lakes were demonstrated by Engloner et al. (2010) and Engloner and Major (2011) who disclosed how genetic diversity changes when stands develop along static water depth gradients. According to their results, genetic diversity - regardless the health status of the stands decreases toward the open water. At the lakeshore where water level never rises above the soil surface, seedling establishment maintains high clonal diversity. In deep water, however, germination is impossible and, if clone settlement from rhizome fragments drifted from other areas is also limited, the presence of reed clones is the outcome of vegetative spreading from the lakeshore. During vegetative spreading, the majority of clones (with low competitive ability) remain at higher elevations and only the most successful clones reach the deepest water. It was also demonstrated that clone size parallel to the shore is considerably larger at the waterside than at the landward edge of the stand and genets successively replace each other in the deepest water, while they form a mixed arrangement at the lakeshore.

In contrast, little is known about how reed propagates in the hydrologically different and diverse riverine habitats (for instance, main channels, side arms and oxbows with or without open inflows, inside or outside the flood protection dams, etc.), where different water regimes may provide various circumstances for reed propagation. It is unclear, 
A.I. Engloner, D. Szegö 2016. Genetic diversity of riverine reed stands indicating the water regime of the habitat. Ecological Indicators 61: 846-849. dx.doi.org/10.1016/j.ecolind.2015.10.037

whether stands developing in different riverine habitats have specific genetic diversity relating to the water regime.

To answer the above questions, the present paper presents the first detailed information on the genetic diversity of riverine reeds.

\section{Materials and methods}

\subsection{Study sites}

Along the Hungarian section of the Danube river, three habitats were selected: (i) an oxbow with significant water level fluctuations related to the flood events in the main river - Nyéki Holt Duna; (ii) a separated oxbow outside the flood protection dams - Riható; and (iii) an artificially controlled running water with low water level fluctuation Soroksári Duna.

Nyéki Holt Duna is an oxbow in the Gemenc floodplain and is located at $1479 \mathrm{rkm}$ on the right bank of the Danube, entirely within the dam system of the river. The total amplitude of water level fluctuation reaches $9 \mathrm{~m}$. The inundation of the floodplain starts at $87.5 \mathrm{~m}$ above the Baltic which corresponds to $650 \mathrm{~cm}$ on the water-gauge in the main river-bed at Baja (Mátrai et al., 2011). The second site, Riha-tó lies on the left bank of the Danube at Mohács (1447 rkm). It has completely lost the connection to the main river channel and became a lake supported by inland inundation. Finally, Soroksári Duna is the second largest side arm of the Danube in Hungary, located between the 1642-1586 rkms and enclosed by sluices at its both ends. The water level fluctuation in this side arm is about 20-60 cm (Vadadi-Fülöp et al., 2007). 
A.I. Engloner, D. Szegő 2016. Genetic diversity of riverine reed stands indicating the water regime of the habitat. Ecological Indicators 61: 846-849. dx.doi.org/10.1016/j.ecolind.2015.10.037

To provide comparability of clonal patterns of the selected riverine stands and the previously investigated lakeside reeds; sampling, genetic investigations and data analysis were carried out exactly in the same way as in Engloner et al. (2010) and Engloner and Major (2011).

\subsection{Sampling}

At each habitat, a 300-500 m long sector of reed stands was investigated along three transects parallel to the shore; Transect I was taken along the landward edge, Transect II was positioned in the middle of the stand and Transect III at the open water edge. At the time of sampling (July 2013), water levels were below the soil surface along Transects I of all study sites, while at the lowest elevations water depths were around 60, 125 and 65 cm at Nyéki Holt Duna, Riha tó and Soroksári Duna, respectively.

Distances between sampling points along the transects ranged from 25 to $35 \mathrm{~m}$ and the total number of samples collected at the Nyéki Holt Duna, Riha tó and Soroksári Duna were 44, 35 and 43, respectively. Where large patches of species other than P. australis occurred inside the investigated stands, the number of samples decreased. That was the situation, for instance, in the Riha-tó, where impassable patches of willow occupied the middle of the reed stand.

\subsection{Genetic investigations}

At all sampling points, strongly growing shoot tips were collected for microsatellite analysis. Genomic DNA from the 122 culm tip samples was isolated using the CTAB 
A.I. Engloner, D. Szegő 2016. Genetic diversity of riverine reed stands indicating the water regime of the habitat. Ecological Indicators 61: 846-849. dx.doi.org/10.1016/j.ecolind.2015.10.037

protocol described by Doyle and Doyle (1987). Following Saltonstall (2003), four microsatellite primer pairs: PaGT14, PaGT16, PaGT21 and PaGT22 (Table 1) were

\section{Table 1}

Microsatellite primer pair sequences and calculated characteristics of alleles and clones

\begin{tabular}{|c|c|c|c|c|c|c|c|}
\hline Locus & $5^{\prime} \rightarrow 3^{\prime}$ sequence & Label & $\mathrm{N}_{\mathrm{A}}$ & $\mathrm{S}(\mathrm{bp})$ & $\mathrm{MN}_{\mathrm{A}}$ & $\mathrm{N}_{\mathrm{P}}$ & $\mathrm{N}_{\mathrm{Ho}}$ \\
\hline PaGT14 & $\begin{array}{l}\text { F: GTTGCAGCAAGTATTTGG } \\
\text { R: CAAGCATTCTAGTAGTAGC }\end{array}$ & VIC & 10 & $182-195$ & 4 & 20 & 17 \\
\hline PaGT16 & $\begin{array}{l}\text { F: ACCAATCAGTCAGACTAGCC } \\
\text { R: GTTCTCATGTTGGAGAAGCC }\end{array}$ & PET & 9 & $225-292$ & 2 & 15 & 12 \\
\hline PaGT21 & $\begin{array}{l}\text { F: GCTACTCAACAGGTATACGG } \\
\text { R: ATTGAGGATTGAGGTGGTGG }\end{array}$ & 6-FAM & 12 & $172-248$ & 5 & 37 & 31 \\
\hline PaGT22 & $\begin{array}{l}\text { F: GTTGAGTGCCTGGTGTATTCG } \\
\text { R: AAGCTTCTGTCATGGAACCG }\end{array}$ & NED & 16 & $182-211$ & 2 & 39 & 31 \\
\hline
\end{tabular}

$\mathrm{N}_{\mathrm{A}}$ : number of alleles detected at the locus, $\mathrm{S}$ : size range of the alleles in base pairs,

$\mathrm{MN}_{\mathrm{A}}$ : maximum number of alleles detected in a genotype, $\mathrm{N}_{\mathrm{P}}$ : number of the observed phenotypes/clones, $\mathrm{N}_{\mathrm{Ho}}$ : number of the observed partial heterozygous clones.

selected. The forward primers were 5'-labelled with 6-FAM, PET, VIC or NED. The reverse primers were PIG-tailed (Brownstein et al., 1996) for increasing the accuracy of the identification of the allelic sizes. PCR amplifications were carried out after Saltonstall (2003). Fragment length polymorphism of the alleles was detected by capillary electrophoresis on an ABI 3130 Genetic Analyser and evaluated by Peak Scanner (ABI).

\subsection{Data analysis}

Clonal composition of the investigated stands was determined on the basis of multilocus phenotypes. Binary character matrices were evaluated by hierarchical clustering [group 
A.I. Engloner, D. Szegö 2016. Genetic diversity of riverine reed stands indicating the water regime of the habitat. Ecological Indicators 61: 846-849. dx.doi.org/10.1016/j.ecolind.2015.10.037

average method (UPGMA) with the complement of simple matching coefficient] using the SYN-TAX 2000 package (Podani, 2001). Ramets were considered to belong to the same clone if they were uniform at all investigated microsatellite loci. The proportion of the distinguishable variations (PD) was calculated for the entire stand and the separate transects as $P D=G / N$, where $G$ is the number of identified clones/genets and $\mathrm{N}$ is sample size (Ellstrand and Roose, 1987).

\section{Results}

The four primer pairs involved in microsatellite comparisons provided a total of 47 polymorphic allelic variants (Table 1) that determined 70 multilocus phenotypes. Based on the allelic phenotypes of the clones, the ploidy level of the investigated stands was considered as tetraploid. There appeared five alleles only in the case of one clone (namely, clone 12 at the Nyéki Holt Duna, represented by one plant sample) for locus PaGT21, however, one of them had small intensity in the fragment length analysis profiles. The latter may indicate hexaploid genotype for the mentioned clone or, alternatively, it may reflect gene duplications or aneuploidy.

The numbers of samples and genets and also the PD values of the three investigated reed stands are presented in Table 2. The locations of clones are shown in Fig. 1. 
A.I. Engloner, D. Szegö 2016. Genetic diversity of riverine reed stands indicating the water regime of the habitat. Ecological Indicators 61: 846849. dx.doi.org/10.1016/j.ecolind.2015.10.037

\section{Table 2}

The numbers of samples $(\mathrm{N})$ and genets $(\mathrm{G})$ and the PD values in the three investigated reed stands

\begin{tabular}{|c|c|c|c|c|c|c|c|c|c|c|c|c|}
\hline & \multicolumn{4}{|c|}{ Nyéki Holt Duna } & \multicolumn{4}{|c|}{ Riha-tó } & \multicolumn{4}{|c|}{ Soroksári Duna } \\
\hline & I & II & III & Total & I & II & III & Total & I & II & III & Total \\
\hline $\mathrm{N}$ & 15 & 14 & 15 & 44 & 15 & 6 & 14 & 35 & 15 & 13 & 15 & 43 \\
\hline G & 7 & 10 & 4 & 14 & 14 & 5 & 10 & 25 & 13 & 11 & 12 & 31 \\
\hline PD & 0.467 & 0.714 & 0.267 & 0.318 & 0.933 & 0.833 & 0.714 & 0.714 & 0.867 & 0.846 & 0.800 & 0.721 \\
\hline
\end{tabular}

Transects are (I) landward edge; (II) middle of the stand and (III) open water edge. 


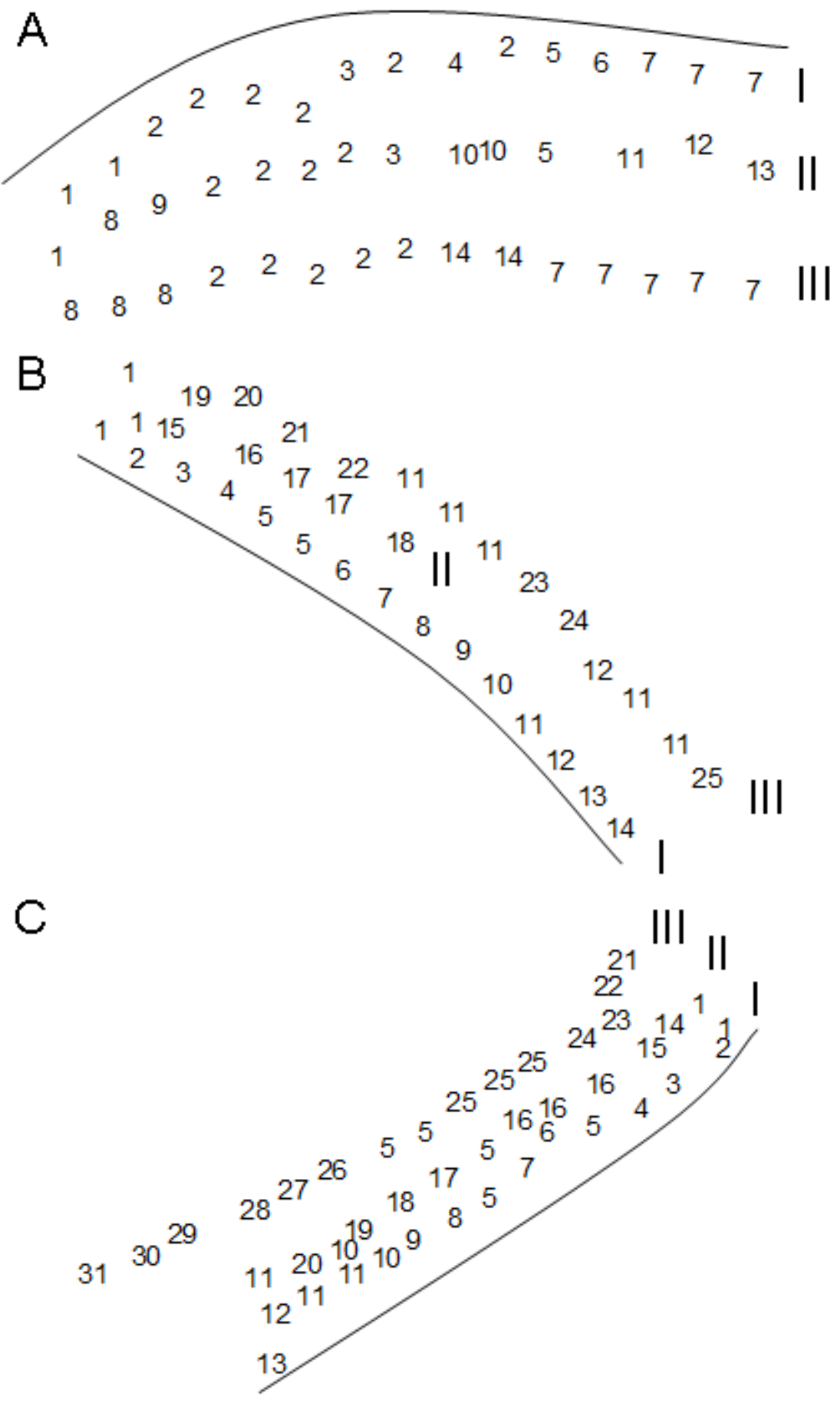

Fig. 1. Location of the clones in the Nyéki Holt Duna (A); the Riha-tó (B) and the

Soroksári Duna (C). Transects parallel to the shore are I: landward edge; II: middle of the stand and III: open water edge. Solid lines illustrate the riverbanks. Same Arabic 
A.I. Engloner, D. Szegő 2016. Genetic diversity of riverine reed stands indicating the water regime of the habitat. Ecological Indicators 61: 846-849. dx.doi.org/10.1016/j.ecolind.2015.10.037

numerals represent plant samples belonging to the same clones and numbering does not refer to genetic similarity. Space between numbers is proportional to in situ distances.

In the Nyéki Holt Duna, low PD values were calculated for both the transects and the whole stand (Table 2). As Fig. 1.A shows, most of the clones revealed in this site were represented by many plants; and only Clones 4, 6, 9, 11, 12 and 13 appeared in a single sample. The lowest genetic diversity was found at the deepest water, however, few and large clones also occurred in the higher elevations. Clones 2 and 7, for instance, had considerable extension both parallel (179 and $96 \mathrm{~m})$ and perpendicular (87 and $85 \mathrm{~m})$ to the bank.

In the Riha-tó, almost all plants belonged to different clones at the landward edge of the stand (Table 2, Fig. 1.B); the only exception was Clone 5 with two plants. At the open water, the largest part of the transect was occupied by one clone, namely Clone 11 which had an extension of 233 m length.

In the Soroksári Duna, the 43 reed samples were classified into 31 different clones. Most of the samples belonged to different clones (high PD values were calculated) in all of the transects, indicating high genetic diversity irrespectively of the distance from the riverbank. Few clones were represented by more than one samples; for instance, the extensions of Clone 11 (Transect I-II), Clone 16 (Transect II) and Clone 25 (Transect III) were $45 \mathrm{~m}, 54 \mathrm{~m}$ and $55 \mathrm{~m}$, respectively (Fig. 1.C). The only large clone was Clone 5 (represented by 5 plants) which appeared in all of the three transects. The largest extension of this clone was $104 \mathrm{~m}$. 


\section{Discussion}

Genetic diversity in reed stands can be increased by generative reproduction, somatic mutations and rhizome fragments drifted from other areas. Although somatic mutation is significant in reed (and frequently cause the overestimation of clonal diversity, see Engloner et al., 2010 and Podani et al., 2009), it is not detected by microsatellite analysis. Therefore, in a stand where clone settlement from 'outer' rhizome fragments is absent (as it was the situation in our investigated riverine habitats), high genetic diversity is the result of germination and seedling development.

Among the possible factors affecting germination and the growth of seedlings, water depth is thought to be one of the most important one (see the review by Engloner (2009) and the literature cited therein). Haslam (1972) reported $5 \mathrm{~cm}$ as the highest water level that allows reed germination. If germination does not take place immediately, disintegration (and also predation) diminishes the amount of seeds available for colonization. Furthermore, seedling development is also a highly vulnerable period. According to Armstrong et al. (1999), any degree of permanent submergence of young seedling shoots greatly reduces (75-100\%) their chance to become emergent.

In lakeside habitats, as it was discussed earlier, seedling establishment maintains high clone diversity at the lakeshore (where water level never rises above the soil surface), but germination is impossible in deep water where, therefore, the clone number is low. Very different genetic diversity was revealed at the Nyéki Holt Duna, the oxbow located in the floodplain of the Danube River; the number of genets was low in the entire site, even in the landward transect, indicating impeded generative reproduction of reed. 
A.I. Engloner, D. Szegö 2016. Genetic diversity of riverine reed stands indicating the water regime of the habitat. Ecological Indicators 61: 846-849. dx.doi.org/10.1016/j.ecolind.2015.10.037

Indeed, in the Gemenc floodplain where the Nyéki Holt Duna is situated, the frequency and duration of floods are high enough to inundate the floodplain and permanently impede either germination or seedling development (water level data of the last one hundred years have been published by Mátrai et al., 2011).

In contrast to the above oxbow, the Riha-tó has lost the connection to the main river channel and has become a lake. Clonal diversity in this habitat was quite similar to that of conventional lakes; many small clones occurred at the landward edge of the stand and few but large clones (the most successful ones with high competitive ability) occupied the deep water. However, the apparent arrangement of clones revealed previously at the open water edge of lakeside reeds (that is genets successively replacing each other, see Engloner et al. 2010 and Engloner and Major 2011) has not been observed here. The reason for this may be that the extension of stand perpendicular to the shore was much higher at the lakeside habitats $(230-250 \mathrm{~m})$ than at Riha-tó $(60-80 \mathrm{~cm})$. This implies that the distance made by the most successful clones toward the open water (and the time for spreading and competing) was shorter at this oxbow than at the lakeside habitats.

Actually, reed stands have had quite different times for colonization and spreading at the two habitats; water levels at the investigated lakeside habitats were similar to the presentday level even during the Roman age, while the oxbow had separated from the main river and become a lake only a couple of hundred years ago. The picture found at the open water edge at the Riha-tó was similar to that revealed in the middle transect (being approximately 100 meters far from the shore) of the lakeside stand.

A very different clonal pattern was found at the Soroksári Duna; high genetic diversity (many small genets) was revealed in all of the three transects, indicating the primary role 
A.I. Engloner, D. Szegő 2016. Genetic diversity of riverine reed stands indicating the water regime of the habitat. Ecological Indicators 61: 846-849. dx.doi.org/10.1016/j.ecolind.2015.10.037

of generative reproduction in the whole stand. Germination in the landward edge is possible, since the water level does not rise here above the soil surface (Soroksári Duna is an artificially controlled side arm). However, the reason for generative reproduction in the middle and at the open water edge of the stand is quite specific; reed in the Soroksári Duna frequently forms floating mats providing appropriate conditions for germination and seedling development even at the open water edge of the stands.

\section{Conclusions}

That clonal diversity was so different in the three stands demonstrates the variety of reed propagation and colonization in riverine habitats. This variety relates to the water regime of the habitat which may affect the proportion of vegetative and reproductive propagation of the species. In floodplains, if the frequency and duration of floods are high and long enough, the chance of generative reproduction may be greatly reduced. Seedling establishment, however, can be considerable if water level fluctuation is controlled or eliminated (by sluices or dams, for instance). When an oxbow has completely lost connection to the main river, reed may develop in the same way as in regular lakes. However, the result of vegetative spreading and competition between clones (for instance, the number and arrangement of the most successful clones at the deepest water) may depend on the distance by the genets. Nevertheless, reed plants can diminish the effect of water level fluctuation if they form floating mats on which the appropriate conditions for germination can be maintained. 


\section{Acknowledgements}

This work was supported by the Hungarian Scientific Research Grant (OTKA K106177) and the János Bolyai Research Scholarship of the Hungarian Academy of Sciences (BO 00513 13). We are grateful to the anonymous referees for their comments and suggestions.

\section{References}

Armstrong, J., Afreen-Zobayed, F., Blyth, S., Armstrong, W., 1999. Phragmites australis: effects of shoot submergence on seedling growth and survival and radial oxygen loss from roots. Aquat Bot. 64, 275-289.

Brownstein, M.J., Carpten, J.D., Smith, J.R,. 1996. Modulation of non-templated nucleotide addition by TaqDNApolymerase: primer modifications that facilitate genotyping. BioTechniques 20, 1004-1010.

Doyle, J.J., Doyle, J.L., 1987. A rapid DNA isolation procedure for small quantities of fresh leaf tissue. Phytochem Bull. 19, 11-15.

Ellstrand, N.C., Roose, M.L., 1987. Patterns of genotypic diversity in clonal plant species. Am J Bot. 74, 123-131. 
A.I. Engloner, D. Szegö 2016. Genetic diversity of riverine reed stands indicating the water regime of the habitat. Ecological Indicators 61: 846-849. dx.doi.org/10.1016/j.ecolind.2015.10.037

Engloner, A. 2009. Structure, growth dynamics and biomass of reed (Phragmites australis) - A review. Flora 204, 331-346.

Engloner, A.I., Major, Á., Podani, J., 2010. Clonal diversity along a water depth gradient in a declining reed stand as detected by three different genetic methods. Aquat Bot. 92, 1-8.

Engloner, A.I., Major, Á., 2011. Clonal diversity of Phragmites australis propagating along water depth gradient. Aquat Bot. 94, 172-176.

Haslam, S.M., 1972. Biological flora of the British Isles. Phragmites communis Trin. J Ecol. 60, 585-610.

Kiviat, E., 2013. Ecosystem services of Phragmites in North America with emphasis on habitat functions. AoB PLANTS 5, plt008.

Koppitz, H., Kühl, H., 2000. To the importance of genetic diversity of Phragmites australis in the development of reed stands. Wetl. Ecol. Manag. 8, 403-414.

Koppitz, H., Kühl, H., Hesse, K., Kohl, J.G., 1997. Some aspects of the importance of genetic diversity in Phragmites australis (Cav.) Trin. ex Steudel for the development of reed stands. Bot. Acta. 110, 217-223.

Mátrai, I., Lakatos, G., Czudar, A., Szlávik, L., 2011. Forecast of changes concerning the water budget in a wetland of Danube Floodplain. J Environ Sci Eng. 5, 523-532.

Neuhaus, D., Kühl, H., Kohl, J.G., Dörfel, P., Börner, T., 1993. Investigation on the genetic diversity of Phragmites stands using genomic fingerprinting. Aquat. Bot. 45, 357-364.

Podani, J., 2001. SYN-TAX 2000. Computer Programs for Data Analysis in Ecology and Systematics. User's Manual. Scientia, Budapest. 
A.I. Engloner, D. Szegö 2016. Genetic diversity of riverine reed stands indicating the water regime of the habitat. Ecological Indicators 61: 846-849. dx.doi.org/10.1016/j.ecolind.2015.10.037

Podani, J., Engloner, A.I., Major, Á., 2009. Multilevel comparison of dendrograms: a new method with an application for genetic classifications. Stat Appl Genet Mol Biol 8, 1-14. Article 22.

Saltonstall, K., 2003. Microsatellite variation within and among North American lineages of Phragmites australis. Mol Ecol. 12, 1689-1702.

Vadadi-Fülöp, Cs., Mészáros, G., Jablonszky, Gy., Hufnagel, L., 2007. Ecology of the Ráckeve-Soroksár Danube — A review. Appl Ecol Environ Res. 5, 133-163. 